\title{
Front Matter: Volume 7946
}

, "Front Matter: Volume 7946," Proc. SPIE 7946, Photonic and Phononic Properties of Engineered Nanostructures, 794601 (4 April 2011); doi: 10.1117/12.891725

SPIE. Event: SPIE OPTO, 2011, San Francisco, California, United States 


\title{
PROCEEDINGS OF SPIE
}

\section{Photonic and Phononic Properties of Engineered Nanostructures}

\author{
Ali Adibi \\ Shawn-Yu Lin \\ Axel Scherer \\ Editors
}

24-27 January 2011

San Francisco, California, United States

Sponsored and published by

SPIE 
The papers included in this volume were part of the technical conference cited on the cover and title page. Papers were selected and subject to review by the editors and conference program committee. Some conference presentations may not be available for publication. The papers published in these proceedings reflect the work and thoughts of the authors and are published herein as submitted. The publisher is not responsible for the validity of the information or for any outcomes resulting from reliance thereon.

Please use the following format to cite material from this book:

Author(s), "Title of Paper," in Photonic and Phononic Properties of Engineered Nanostructures, edited by Ali Adibi, Shawn-Yu Lin, Axel Scherer, Proceedings of SPIE Vol. 7946 (SPIE, Bellingham, WA, 2011) Article CID Number.

ISSN 0277-786X

ISBN 9780819484833

Published by

SPIE

P.O. Box 10, Bellingham, Washington 98227-0010 USA

Telephone +1 3606763290 (Pacific Time) · Fax +1 3606471445

SPIE.org

Copyright (C) 2011, Society of Photo-Optical Instrumentation Engineers

Copying of material in this book for internal or personal use, or for the internal or personal use of specific clients, beyond the fair use provisions granted by the U.S. Copyright Law is authorized by SPIE subject to payment of copying fees. The Transactional Reporting Service base fee for this volume is $\$ 18.00$ per article (or portion thereof), which should be paid directly to the Copyright Clearance Center (CCC), 222 Rosewood Drive, Danvers, MA 01923. Payment may also be made electronically through CCC Online at copyright.com. Other copying for republication, resale, advertising or promotion, or any form of systematic or multiple reproduction of any material in this book is prohibited except with permission in writing from the publisher. The CCC fee code is $0277-786 \mathrm{X} / 11 / \$ 18.00$.

Printed in the United States of America.

Publication of record for individual papers is online in the SPIE Digital Library.

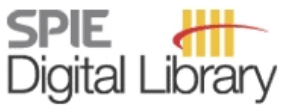

SPIEDigitalLibrary.org

Paper Numbering: Proceedings of SPIE follow an e-First publication model, with papers published first online and then in print and on CD-ROM. Papers are published as they are submitted and meet publication criteria. A unique, consistent, permanent citation identifier (CID) number is assigned to each article at the time of the first publication. Utilization of CIDs allows articles to be fully citable as soon as they are published online, and connects the same identifier to all online, print, and electronic versions of the publication. SPIE uses a six-digit CID article numbering system in which:

- The first four digits correspond to the SPIE volume number.

- The last two digits indicate publication order within the volume using a Base 36 numbering system employing both numerals and letters. These two-number sets start with $00,01,02,03,04$, $05,06,07,08,09,0 A, 0 B \ldots 0 Z$, followed by 10-1Z, 20-2Z, etc.

The CID number appears on each page of the manuscript. The complete citation is used on the first page, and an abbreviated version on subsequent pages. Numbers in the index correspond to the last two digits of the six-digit CID number. 


\section{Contents}

ix Conference Committee

RECENT ADVANCES IN ENGINEERED NANOSTRUCTURES

794605 Acoustic metamaterials based on the homogenization of periodic scatterers (Invited Paper) [7946-04]

J. Sánchez-Dehesa, D. Torrent, Univ. Politécnica de Valencia (Spain)

PHOTONIC CRYSTAL LIGHT EMITTERS

794606 High peak power (34 W) photonic crystal distributed feedback quantum cascade lasers (Invited Paper) [7946-05]

B. Gökden, Y. Bai, N. Bandyopadhyay, S. Slivken, M. Razeghi, Northwestern Univ. (United States)

794607 Surface emitting laser based on random photonic crystals [7946-06]

S. Takeda, Keio Univ. (Japan) and Ecole Centrale de Lyon (France); S. Hamada, Keio Univ. (Japan); R. Peretti, C. Seassal, X. Letartre, P. Viktorovitch, Ecole Centrale de Lyon (France); M. Obara, Keio Univ. (Japan)

794608 Purcell-enhanced single-photon emission from an InP quantum dot coupled to GalnP photonic crystal nanocavity [7946-07]

I. J. Luxmoore, E. D. Ahmadi, N. A. Wasley, A. I. Tartakovskii, A. M. Fox, A. B. Krysa,

M. S. Skolnick, The Univ. of Sheffield (United Kingdom)

\section{PHOTONIC CRYSTAL RESONATORS}

7946 OB Nonlinear optics in photonic crystal nanocavities: from light sources to quantum photonic interfaces (Invited Paper) [7946-10]

K. Rivoire, S. Buckley, A. Majumdar, G. Shambat, J. Vučković, Stanford Univ. (United States)

7946 OE Optical microcavities clad by transparent conductive oxides [7946-13]

O. Senlik, L. Tang, P. Tor-ngern, T. Yoshie, Duke Univ. (United States)

\section{MODELING AND SIMULATION OF PHOTONIC CRYSTAL STRUCTURES}

7946 OG Finite difference simulation of thermally funed hexagonal photonic crystals [7946-15]

S. R. Newman, R. C. Gauthier, Carleton Univ. (Canada)

7946 0J Theoretical analysis of the order to disorder phase transition in random photonic crystals [7946-18]

S. Hamada, Keio Univ. (Japan); S. Takeda, Keio Univ. (Japan) and Institute des

Nanotechnologies de Lyon, CNRS (France); P. Viktorovitch, Institute des Nanotechnologies

de Lyon, CNRS (France); M. Terakawa, M. Obara, Keio Univ. (Japan) 
7946 OK Colloidal co-assembly route to large-area high-quality photonic crystals (Invited Paper) [7946-19]

L. Mishchenko, B. Hatton, I. B. Burgess, Harvard Univ. (United States); S. Davis, K. Sandhage,

Georgia Institute of Technology (United States); J. Aizenberg, Harvard Univ. (United States)

7946 OM Woodpile photonic crystal of various crystal orientations [7946-21]

L. Tang, S.-Y. Su, T. Yoshie, Duke Univ. (United States)

PHOTONIC METAMATERIALS

7946 OS Broadband circular polarizer formed by stacked plasmonic metasurfaces (Invited Paper) [7946-27]

Y. Zhao, A. Alù, The Univ. of Texas at Austin (United States)

7946 OU Controlling ultrafast light with dispersive metamaterials [7946-29]

D. P. Brown, UES, Inc. (United States); M. Walker, General Dynamics Information Technology (United States); A. M. Urbas, Air Force Research Lab. (United States)

7946 OV Inverting scattered fields for sub-wavelength resolution using negative index metamaterials [7946-30]

Y. Zhang, Nanyang Technological Univ. (Singapore); M. A. Fiddy, The Univ. of North Carolina at Charlotte (United States)

\section{PHOTONIC CRYSTAL FIBERS}

7946 OX Low loss and broadband hollow-core photonic crystal fibers (Invited Paper) [7946-32] Y. Y. Wang, Univ. of Bath (United Kingdom); F. Gerome, G. Humbert, J. M. Blondy, Xlim, Univ. de Limoges, CNRS (France); F. Benabid, Univ. of Bath (United Kingdom) and Xlim, Univ. de Limoges, CNRS (France)

7946 OY Novel aspects of pulse propagation in photonic crystal fibers (Invited Paper) [7946-33] S. P. Stark, A. Podlipensky, Max-Planck Institute for the Science of Light (Germany); P. St. J. Russell, Max-Planck Institute for the Science of Light (Germany) and Univ. of Erlangen-Nuremberg (Germany)

$79460 Z$ Selective filling of metals into photonic crystal fibers [7946-34]

R. Spittel, D. Hoh, S. Brückner, A. Schwuchow, K. Schuster, J. Kobelke, H. Bartelt, Institute of Photonic Technology Jena (Germany)

794610 Improved laser damage threshold for chalcogenide glasses through surface microstructuring [7946-35]

C. Florea, GTEC Inc. (United States); J. Sanghera, L. Busse, B. Shaw, I. Aggarwal, Naval Research Lab. (United States)

\section{NOVEL PHENOMENA IN PHOTONIC CRYSTALS}

794614 Photonic crystal waveguide based sensors [7946-39]

M. Askari, S. Yegnanarayanan, A. Adibi, Georgia Institute of Technology (United States) 
794615 Manipulation of thermal phonons: a phononic crystal route to High-ZT thermoelectrics (Invited Paper) [7946-83]

I. El-Kady, Sandia National Labs. (United States); M. F. Su, The Univ. of New Mexico (United States); C. M. Reinke, P. E. Hopkins, Sandia National Labs. (United States); D. Goettler, Z. C. Leseman, The Univ. of New Mexico (United States); E. A. Shaner, R. H. Olsson III, Sandia National Labs. (United States)

794618 Is there really a sound line limit for surface waves in phononic crystals? (Invited Paper) [7946-42]

S. Benchabane, Institut Femto-ST, CNRS, Univ. de Franche-Comté (France); A. Khelif, International Joint Lab. GeorgiaTech-CNRS (France); V. Laude, Institut Femto-ST, CNRS, Univ. de Franche-Comté (France)

\section{PLASMONIC STRUCTURES FOR SENSING APPLICATIONS}

7946 1A Plasmo-photonic nanopillar array for large-area surface-enhanced Raman scattering sensors [7946-44] F. J. Bezares, J. D. Caldwell, O. J. Glembocki, R. W. Rendell, U.S. Naval Research Lab. (United States); M. Ukaegbu, Howard Univ. (United States); R. Kasica, Ctr. for Nanoscale Science and Technology, NIST (United States); M. Feygelson, S. M. Prokes, M. Papantonakis, U.S. Naval Research Lab. (United States); C. Hosten, Howard Univ. (United States)

7946 IC InGaAsP photonic crystal slot nanobeam waveguides for refractive index sensing [7946-46] B. Wang, Eindhoven Univ. of Technology (Netherlands) and Zhejiang Univ. (China); M. A. Dündar, R. Nötzel, F. Karouta, Eindhoven Univ. of Technology (Netherlands); S. He, Zhejiang Univ. (China); R. W. van der Heijden, Eindhoven Univ. of Technology (Netherlands)

7946 ID On-chip nanostructures for polarization imaging and multispectral sensing using dedicated layers of modified CMOS processes [7946-47]

S. Junger, W. Tschekalinskij, N. Verwaal, N. Weber, Fraunhofer Institute for Integrated Circuits (Germany)

\section{RESONANCE-BASED PLASMONIC STRUCTURES}

$7946 \mathrm{1H} \quad$ Efficient coupling to plasmonic nanoresonators using on-chip silicon nitride integrated photonic structures [7946-51]

M. Chamanzar, S. Yegnanarayanan, E. Shah Hosseini, A. Adibi, Georgia Institute of Technology (United States)

$794611 \quad$ A new class of plasmonic crystals: the eigen modes, field enhancement, and applications [7946-52]

M. Iwanaga, National Institute for Materials Science (Japan) and PRESTO, Japan Science and Technology Agency (Japan) 
7946 1K Engineering aperiodic order in nanoplasmonics: past, present, and future opportunities (Invited Paper) [7946-54]

L. Dal Negro, Boston Univ. (United States)

$79461 \mathrm{M}$ Study of nanoprisms via apertureless near-field optical microscopy [7946-56]

C.-F. Cheang, Y.-C. Li, K.-C. Chiu, C.-Y. Lin, Y.-C. Chang, S.-J. Chen, National Cheng Kung Univ. (Taiwan)

7946 iN Development of a polarization resolved mid-IR near-field microscope [7946-57]

Z. Sedaghat, A. Bruyant, Univ. de Technologie Troyes (France); M. Kazan, American Univ. of Beyrouth (Lebanon); J. Vaillant, S. Blaize, Univ. de Technologie Troyes (France); N. Rochat, N. Chevalier, Commissariat à l'Énergie Atomique (France); E. Garcia-Caurel, Lab. de Physique des Interfaces et Couches Minces (France); P. Morin, ST-Microelectronics (France); P. Royer, Univ. de Technologie Troyes (France)

\section{NOVEL PHENOMENA IN PLASMONIC STRUCTURES II}

7946 1Q High-throughput engineering of infrared plasmonic nanoantenna arrays with nanostencil lithography [7946-60]

S. Aksu, A. A. Yanik, R. Adato, A. Artar, M. Huang, H. Altug, Boston Univ. (United States)

7946 IR Multipolar second harmonic generation from metallic nanoparticles [7946-61]

J. Butet, G. Bachelier, I. Russier-Antoine, Ch. Jonin, E. Benichou, P. F. Brevet, Lab. de

Spectrométrie Ionique et Moléculaire, CNRS, Univ. Claude Bernard Lyon 1 (France)

7946 is Nanoplasmonic photonic crystal diatoms and phytoliths [7946-62]

M. P. Andrews, A. Hajiaboli, J. Hiltz, T. Gonzalez, G. Singh, R. B. Lennox, McGill Univ. (Canada)

DESIGN AND CHARACTERIZATION OF PLASMONIC STRUCTURES

7946 IT Observation of full plasmonic stop bands in fractal structures [7946-64]

N. Yasrebi, S. Khorasani, Sharif Univ. of Technology (Iran, Islamic Republic of); A. Hazeghi, Stanford Univ. (United States); B. Rashidian, Sharif Univ. of Technology (Iran, Islamic Republic of)

7946 IU Mapping of surface plasmon polaritons on nanostructured thin film disks using cathodoluminescence imaging [7946-65]

A. Kumar, K. H. Fung, Univ. of Illinois at Urbana-Champaign (United States); N. X. Fang, Univ. of Illinois at Urbana-Champaign (United States) and Massachusetts Institute of Technology (United States)

$79461 \mathrm{~V}$ Description and characterization of the complex modes in a linear chain of gold nanospheres [7946-66]

S. Campione, Univ. of California, Irvine (United States); S. Steshenko, Univ. of Siena (Italy) and Institute of Radiophysics and Electronics (Ukraine); F. Capolino, Univ. of California, Irvine (United States) 
7946 IW Revisiting the Jaynes-Cummings-Paul model in the limit of ultrastrong coupling [7946-67] E. Ahmadi, Sharif Univ. of Technology (Iran, Islamic Republic of); H. R. Chalabi, Stanford Univ. (United States); A. Arab, S. Khorasani, Sharif Univ. of Technology (Iran, Islamic Republic of)

7946 1X Wannier functions for surface plasmon polaritons [7946-68] A. Hazeghi, S. Khorasani, Sharif Univ. of Technology (Iran, Islamic Republic of)

7946 IY Numerical simulation and rational design of optically anisotropic columnar films [7946-69] V. A. Leontyev, Univ. of Alberta (Canada) and NRC National Institute for Nanotechnology (Canada); M. M. Hawkeye, N. G. Wakefield, Univ. of Alberta (Canada); K. Tabunshchyk, NRC National Institute for Nanotechnology (Canada); J. C. Sit, Univ. of Alberta (Canada); A. Kovalenko, M. J. Brett, Univ. of Alberta (Canada) and NRC National Institute for Nanotechnology (Canada)

794620 Experimental demonstration of linear deep subwavelength spoof surface plasmonic waveguides [7946-71]

W. Zhao, O. M. Eldaiki, R. Yang, Rochester Institute of Technology (United States); X. Huang, Michigan Technological Univ. (United States); Z. Lu, Rochester Institute of Technology (United States)

794621 Nanostructured metal-insulator-metal resonators for high-resolution color filtering and spectral imaging [7946-72]

T. XU, Y.-K. WU, L. J. Guo, Univ. of Michigan (United States)

794623 Analysis of triangular ring resonator using microcavity SOI slot waveguides [7946-74] T.-K. Lee, H.-S. Kim, G.-Y. Oh, Y.-W. Choi, Chung-Ang Univ. (Korea, Republic of)

794625 Enhancement and suppression of transmission in 3D nanoslits arrays with 1- and 2D periodicities [7946-76]

M. A. Vincenti, D. de Ceglia, The AEgis Technologies Group, Inc. (United States); M. Scalora, Charles M. Bowden Research Ctr., RDECOM (United States); R. Marani, V. Marrocco,

M. Grande, G. Morea, A. D'Orazio, Politecnico di Bari (Italy)

794626 Investigation of the nonlinear optical response from arrays of Au bowtie nanoantennas [7946-78]

K. D. Ko, A. Kumar, K. H. Fung, R. Ambekar, G. L. Liu, N. X. Fang, K. C. Toussaint, Jr., Univ. of Illinois at Urbana-Champaign (United States)

794627 Simulation of photonic bandgaps in real holographically formed 3D photonic crystals and holographic fabrication [7946-79]

Y. Lin, K. Ohlinger, H. Zhang, Univ. of North Texas (United States); D. XU, K. P. Chen, Univ. of Pittsburgh (United States)

794629 Anderson localization of light in a random configuration of semiconductor nanocolumns [7946-81]

Y. Inose, Sophia Univ. (Japan) and CREST, Japan Science and Technology Agency (Japan); M. Sakai, Univ. of Yamanashi (Japan); K. Ema, A. Kikuchi, K. Kishino, T. Ohtsuki, Sophia Univ. (Japan) and CREST, Japan Science and Technology Agency (Japan)

Author Index 
Downloaded From: https://www.spiedigitallibrary.org/conference-proceedings-of-spie on 26 Apr 2023

Terms of Use: https://www.spiedigitallibrary.org/terms-of-use 


\title{
Conference Committee
}

\author{
Symposium Chair
}

Liang-Chy Chien, Kent State University (United States)

Symposium Cochairs

Klaus P. Streubel, OSRAM GmbH (Germany)

E. Fred Schubert, Rensselaer Polytechnic Institute (United States)

Program Track Chair

Ali Adibi, Georgia Institute of Technology (United States)

\section{Conference Chairs}

Ali Adibi, Georgia Institute of Technology (United States)

Shawn-Yu Lin, Rensselaer Polytechnic Institute (United States)

Axel Scherer, California Institute of Technology (United States)

Program Committee

Shanhui Fan, Stanford University (United States)

Abdelkrim Khelif, International Joint Laboratory GeorgiaTech-CNRS (France)

Maryanne C. J. Large, The University of Sydney (Australia)

Susumu Noda, Kyoto University (Japan)

Masaya Notomi, NTT Basic Research Laboratories (Japan)

Ekmel Özbay, Bilkent University (Turkey)

Domenico Pacifici, California Institute of Technology (United States)

Dennis W. Prather, University of Delaware (United States)

William J. Wadsworth, University of Bath (United Kingdom)

Yong Xu, Virginia Polytechnic Institute and State University (United States)

Eli Yablonovitch, University of California, Berkeley (United States)

Session Chairs

1 Recent Advances in Engineered Nanostructures

Ali Adibi, Georgia Institute of Technology (United States)

2 Photonic Crystal Light Emitters

Sameer Walavalkar, California Institute of Technology (United States) 
3 Photonic Crystal Resonators

Marko Loncar, Harvard University (United States)

$4 \quad$ Modeling and Simulation of Photonic Crystal Structures

Marko Loncar, Harvard University (United States)

$5 \quad$ Three-dimensional Photonic Crystal Structures

Andrea Alù, The University of Texas at Austin (United States)

6 Photonic Metamaterials I

Ekmel Özbay, Bilkent University (Turkey)

7 Photonic Metamaterials II

Harald W. Giessen, Universität Stuttgart (Germany)

8 Photonic Crystal Fibers

Elison Matioli, University of California, Santa Barbara (United States)

9 Novel Phenomena in Photonic Crystals

Charles M. Reinke, Sandia National Laboratories (United States)

10 Phononic Crystal Structures

Ali Adibi, Georgia Institute of Technology (United States)

11 Plasmonic Structures for Sensing Applications

Saeed Mohammadi, Georgia Institute of Technology (United States)

12 Resonance-based Plasmonic Structures

Rashid Zia, Brown University (United States)

13 Novel Phenomena in Plasmonic Structures I

Kenneth B. Crozier, Harvard University (United States)

14 Novel Phenomena in Plasmonic Structures II

Luca Dal Negro, Boston University (United States)

15 Design and Characterization of Plasmonic Structures

Jennifer A. Dionne, University of California, Berkeley (United States) 